\title{
The trends in the main thalweg path of selected reaches of the Middle Vistula River, and their relationships to the geological structure of river channel zone
}

https://doi.org/10.1515/geo-2018-0044

Received May 12, 2018; accepted Aug 18, 2018

Abstract: Research carried out by the authors' team in the valleys of many rivers in the Polish Lowlands has shown that the contemporary morphodynamics of channel zones is highly influenced by protrusions of erosion-resistant sub-alluvial bedrock. The article presents the results of analysis of two reaches of the Middle Vistula: near Solec nad Wisłą (km 330-340) and Gołąb (km 382-388), where such protrusions have been found. At each of them, two series of bathymetric measurements were carried out during medium and low water levels in the river channel. The measurements were made using hydrographic sets integrated with a GNSS receiver. The first series of measurements was carried out in July 2004, and the second one in September 2016. In parallel with the bathymetric surveys, low-altitude aerial photographs were taken in 2016 to document the morphology of the channel zone and the condition of the river engineering structures. A comparison of the obtained bathymetric maps shows a high correspondence between the thalweg line from 2004 and that observed twelve years later. This phenomenon proves the significance of the bedrock relief beneath the modern alluvial deposits for the water flow process in the channel. The relief causes the flow to concentrate in specific zones so strongly that it contributes to the damage of river engineering structures that put limits on the channel processes. This trend of concentrating the main thalweg is also accompanied by the diversity of depositional environments of river channel facies, identified along the studied reaches.

Keywords: Vistula River channel, sub-alluvial bedrock, bathymetric measurements, river engineering structures, aerial images

*Corresponding Author: Tomasz Falkowski: Faculty of Civil and Environmental Engineering, Warsaw University of Life

\section{Introduction}

A channel (channel zone) is an indicator for the river valley environment, and its morphodynamic character is treated as basis for numerous classifications of river systems. Stability of the channel pattern, as well as stability of the thalweg line, can have both local and regional causes. In young rivers (according to Davis [1]), which flow through areas of outcropping solid rocks [2, 3], the channel/thalweg stability may result from the presence of outcrops of rocks resistant to erosion $[4,5]$. Stabilisation of the channel and the thalweg line in mature rivers with a developed erosional base (see Falkowski [6]) may result from the resistance of older channel alluvial series of the same river to erosion. It may be caused by the diversity of transport competencies in the river at various stages of its evolution [6-8]. Stability of the river channel may also result from the presence of features formed by the river in the valley, which are erosion-resistant under the given flow regime conditions. These can be series of cohesive flood deposits [9], residual lags [10], and even rocky bog iron formations that develop in systems of old riverbeds [6].

In case of alluvial channels (in an alluvial layer of channel facies), the channel stability may result from the balance in alluvial deposits. The reasons for this balance may be the result of interactions between local and regional processes affecting the valley [11-13]. The balanced alluvial sediments may help stabilise the channel position and lead to significant advancement of soil processes

Sciences-SGGW, Nowoursynowska 166 st., 02-787 Warsaw; Email: tomasz_falkowski@sggw.pl

Piotr Ostrowski, Marek Bogucki: Faculty of Civil and Environmental Engineering, Warsaw University of Life Sciences - SGGW, Nowoursynowska 166 st., 02-787 Warsaw

Dariusz Karczmarz: Division for Aeronautical Training Systems \& Air Force Comand \& Control, Air Force Institute of Technology, Księcia Bolesława 6 st., 01-494 Warsaw 
on the floodplain. An example of this type of record of a balanced fluvial environment in the Subatlantic period of the Holocene in the Middle Vistula River was presented by Falkowski [11]. That case is illustrated by a model of fluvial environment development, proposed by Schumm [14], in which, periods of intense erosion or accumulation are interspersed by periods of its dynamic equilibrium.

Some river systems (e.g. anastomosing rivers [15]) are characterised, by their very nature, by the stability of the geometry of their channels/multi-channel systems, which is associated with both the low-energy flow and the effect of plant cover. The significance of vegetation in the stabilisation of lowland river channels has been described in many works by Gurnell [16].

Other factors stabilising the channel system are riverengineering and flood protection structures. Their presence in the river channel is aimed at constraining specific flow characteristics. This is why hydro-engineering structures are in most cases opposed to the natural trends in the course of channel processes [17]. This sometimes leads to their damage $[10,18]$, which justifies the need for constant monitoring and maintenance of both the components of the hydro-engineering structures and flood embankments. River engineering facilities also strengthen the impact of natural features of the geological structure on channel processes in the channel zone. These features include, in particular, protrusions of sub-alluvial bedrock deposits that are resistant to erosion [19]. Both the river engineering structures in the channel (e.g. bank revetments, groynes) and the system of flood embankments limit the river's ability to adapt its channel shape to the rising flood wave, which induces an intense process of bottom erosion by flood water (cf. Leopold et al. 1964 [20]). In such conditions, there is an increase of the possibility that the suballuvial bedrock affects the water flow in the channel. The phenomenon of such synergy was the subject of research conducted by us in the Middle Vistula River.

The work aimed at determining to what extent the thalweg path of a modern river is controlled by the geological structure and hydro-engineering facilities. Detailed investigations were carried out on two reaches of the Middle Vistula River channel zone, which can be recognised as representative of the Polish Lowlands area based on earlier experiences of the authors $[6,19]$ : in the Solec nad Wisła and Gołąb regions (Figure 1). The specificity of the course of modern channel processes in both reaches results from differences in the geological structure of the valley. Solec nad Wisłą is located within the Małopolska Gorge of the Vistula River. Detailed investigations covered a 10-km long river channel zone from $\mathrm{km} 330$ (near Solec nad Wisłą) to $\mathrm{km} 340$ (at the Iłżanka River tributary) of the river course.
In this zone the Vistula River valley is incised into the Cretaceous solid rocks: limestones, marls, opokas, gaizes and chalk [21]. The second river reach in the village of Gołąb represents a fully lowland river. In this area, detailed investigations covered a channel zone from $\mathrm{km} 382$ to $\mathrm{km}$ 388 , where the bedrock within the valley is composed of Paleogene deposits: gaizes, limestones and marls [22].

The Vistula riverbed in both these zones is of braided type [23]. The degree of channel engineering is estimated at approximately $80 \%$. The hydro-engineering structures have largely been degraded [24].

\section{Materials and Methods}

The most important operations that were carried out within the framework of the research included the recognition of the geological structure of the channel zone and bathymetric measurements aimed at determining the channel bottom relief, with particular reference to the main thalweg path. To assess the stability of the main thalweg path, it was decided to perform two series of bathymetric measurements over the longest time possible.

The geological research included mapping of the floodplain, registration of profiles of contemporary alluvial deposits in shore exposures, and geological drilling in the riverbed. The work was carried out using a 90-mmdiameter Eijlkelkam manual drilling set. Twelve boreholes were drilled in the Solec nad Wisła region, and 19 in the Gołąb region. The results of the boreholes made it possible to present the surface relief of the immediate sub-alluvial bedrock in the form of a contour map (Figure 2D, Figure 3D)

Two series of echo-sounding surveys were conducted on the selected river reaches during low-water periods: in July 2004 and in September 2016. In 2004, measurements were made seven years after the record high rainfall in July 1997 [25], which caused a catastrophic flood in the Vistula basin. The second series of research was successfully conducted 6 years after another catastrophic flood of the same genesis that took place in the Vistula valley in July 2010. A similar time distance from extreme events allowed us to consider their results as comparable.

In both cases, a hydrographic set consisting of an echo sounder integrated with a DGPS receiver Magellan FX324 Map Color, operating in the EGNOS (European Geostationary Navigation Overlay Service) system, was used. In the 2004 research, an Ohmex "SonarLite" echo sounder, 190 - $210 \mathrm{KHz}$ and with a beamwidth of $10^{\circ}$, was used. In 2016, a Konsberg two-channel EA 400SP echo sounder, 38 and $200 \mathrm{KHz}$ and with a beamwidth of $13^{\circ}$ (Figure 4), 


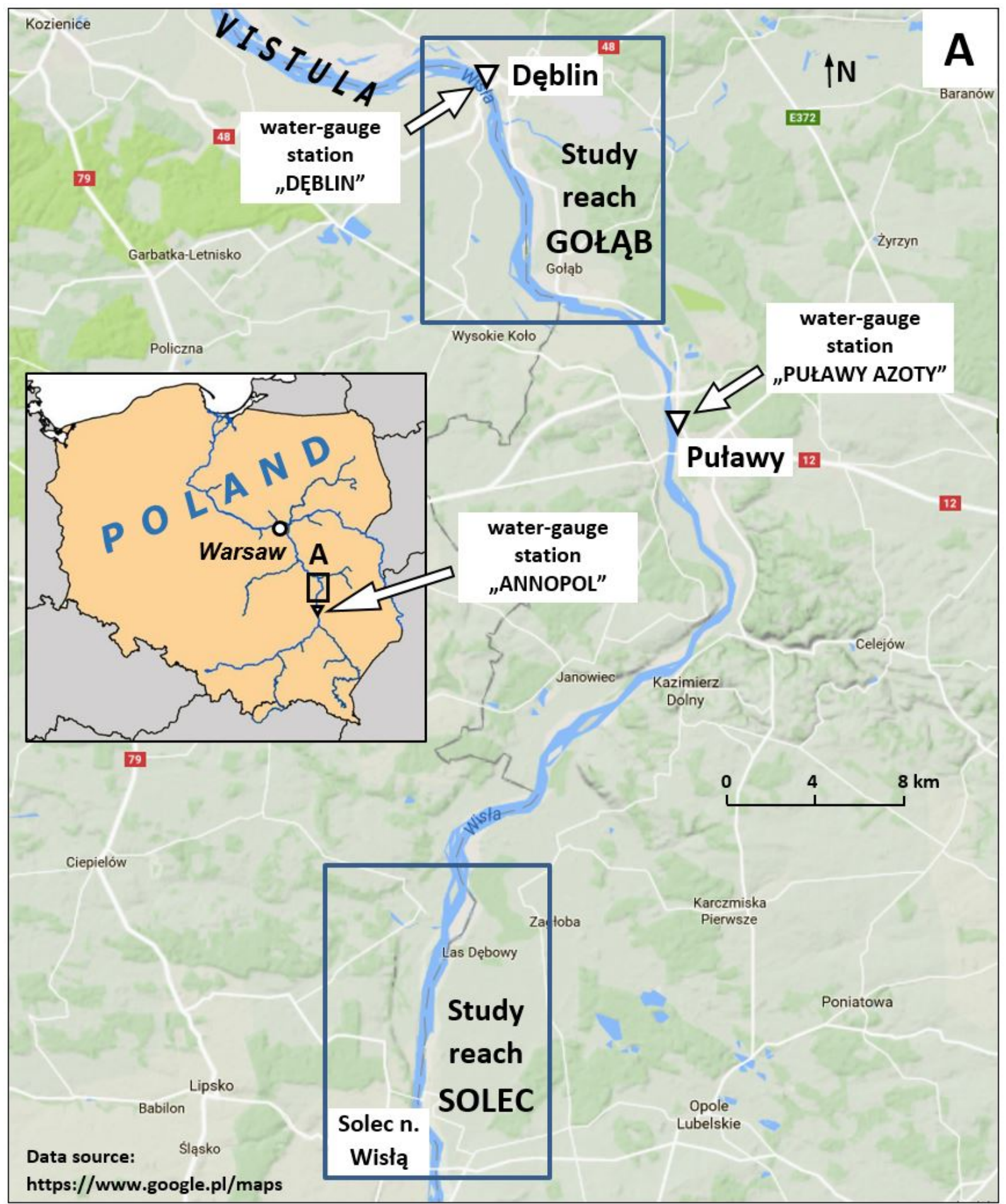

Figure 1: Location of studied reaches and gauge stations mentioned in the text (table 1)

was employed. For all measurements, the speed of generated pulses was $1470 \mathrm{~m} / \mathrm{s}$, and the minimum depth of the channel allowing for a reliable measurement was $0.5 \mathrm{~m}$. Due to the nature of the Vistula riverbed (varied depth, numerous parts of damaged hydro-technical facilities), the hydrographic sets were installed on a small shallow-draft pontoon, $4.2 \mathrm{~m}$ in length.

Due to both the small depth of significant parts of the river channel, which made it impossible to carry out hydrographic measurements, and the occurrence of numer- 

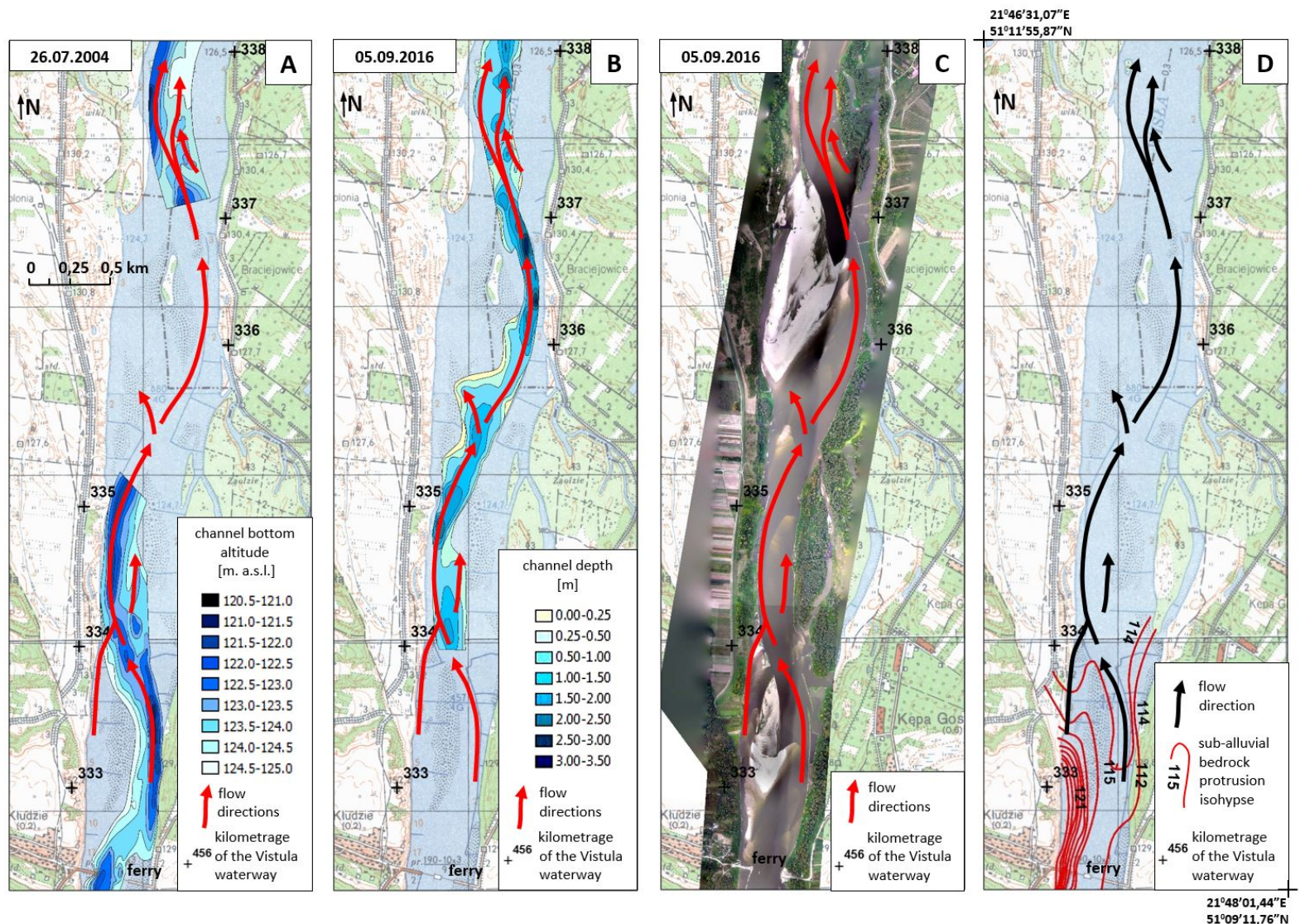

Figure 2: Vistula river thalweg lines arrangement near Solec nad Wisłą

Table 1: The water levels and discharges in the Vistula channel at selected water gauges in time performing bathymetric tests and flood in 2010

\begin{tabular}{|c|c|c|c|c|c|c|}
\hline \multirow[t]{2}{*}{ Date } & \multicolumn{2}{|c|}{$\begin{array}{c}\text { water-gauge station } \\
\text { „DĘBLIN” }\end{array}$} & \multicolumn{2}{|c|}{$\begin{array}{l}\text { water-gauge station } \\
\text { „PUŁAWY AZOTY” }\end{array}$} & \multicolumn{2}{|c|}{$\begin{array}{l}\text { water-gauge station } \\
\text { „ANNOPOL” }\end{array}$} \\
\hline & $\begin{array}{l}\text { water level* } \\
{[\mathrm{cm}]}\end{array}$ & $\begin{array}{c}\text { discharge } \\
{\left[\mathrm{m}^{3} \mathrm{~s}^{-1}\right]}\end{array}$ & $\begin{array}{l}\text { water level* } \\
{[\mathrm{cm}]}\end{array}$ & $\begin{array}{c}\text { discharge } \\
{\left[\mathrm{m}^{3} \mathrm{~s}^{-1}\right]}\end{array}$ & $\begin{array}{l}\text { water level* } \\
{[\mathrm{cm}]}\end{array}$ & $\begin{array}{c}\text { discharge } \\
{\left[\mathrm{m}^{3} \mathrm{~s}^{-1}\right]}\end{array}$ \\
\hline 20.07 .2004 & 162 & 223 & 126 & 171 & 210 & 163 \\
\hline 26.07 .2004 & 171 & 246 & 142 & 204 & 236 & 230 \\
\hline 20.05 .2010 & 608 & 5210 & 736 & 5170 & 714 & 5180 \\
\hline 03.09 .2016 & 148 & 216 & 120 & 190 & 208 & 185 \\
\hline 05.09 .2016 & 145 & 206 & 116 & 184 & 207 & 181 \\
\hline
\end{tabular}

${ }^{\star}$ water level referred to the zero gauge

ous channel mesoforms (sand bars), it was decided to perform a full survey of the channel zone by remote sensing. For this purpose, in 2016, along with the bathymetric measurements, low-altitude aerial photographs of both studied zones were taken [26]. An ultralight aircraft produced by Sonex Aircraft LLC, equipped with a Sony EC75000 nonmetric camera, was used in the research. Images of the Vistula channel area were taken from an altitude of $300 \mathrm{~m}$ with an average cruising speed of $180 \mathrm{~km} / \mathrm{h}$. Because of the low altitude and the wide width of the Vistula channel, acquisition of the images for the entire channel zone required performing three air raids during one research flight. Based on the aerial images, photographic mosaics of the channel area were generated using the Agosoft PhotoScan 1.4.2 software from Agosoft LLC, which were then imported to the GIS database.

As the direct effect of the echo-sounding measurements, bathymetric maps of the river channel were con- 
structed. The interpolation of point depth measurements was performed with the Surfer 10 software using the kriging method. The measurement data before interpolation were supplemented with the results obtained by classical methods. This applied to zones with a depth of less than $0.5 \mathrm{~m}$, to the channel boundaries, and to the channel mesoforms. The bathymetric maps represented by information layers in a vector format were imported to the GIS database for a joint analysis with remote sensing materials - photographic mosaics generated based on aerial images. The database was also supplemented with the results of boreholes and geological soundings of the channel bottom, and the results of mapping of channel forms, which were carried out in both 2004 and 2016. All in-office work, except for the interpolation of results of hydrographic measurements and the preparation of photographic mosaics, were carried out in the GIS database using the ArcGIS 10.5 software from ESRI Inc.

\section{Results}

\subsection{Geological structure of the river channel}

\subsubsection{Solec nad Wistą region}

The sub-alluvial bedrock in this reach is represented by Lower Maastrichtian glauconitic marls, limestones and opokas overlain by a loamy weathering mantle containing opoka and marl clasts and well-rounded quartz grains. Pebbles of Scandinavian crystalline rocks are sporadically found in boreholes. The top surface of sub-alluvial bedrock forms a trough running in line with the course of the contemporary river channel.

The zone of the protrusions of erosion-resistant suballuvial bedrock stretches along the river channel from $\mathrm{km}$ $332+500$ to $\mathrm{km} 334$ (Figures 2D, 5). As evidenced by interpretation of the results of boreholes drilled in this area, the maximum elevation values of the top bedrock surface near the left bank (underneath a steep scarp of the upland area, transected by narrow and deep gorges) attain $123 \mathrm{~m}$ a.s.l. In the central part of the channel, the surface descends to an elevation of ca. $114 \mathrm{~m}$ a.s.l., and near the right bank it lies at approximately $116-117 \mathrm{~m}$ a.s.l. The top surface of sub-alluvial bedrock probably ascends east of the Vistula channel, forming a domal culmination there. Further east there is an arcuate erosional trough - a wide by-pass used by flood flows. In this place, an erosional trough from the Mazovian Interglacial is marked, which is deeply incised into the Upper Cretaceous rocks [21, 27].
The contemporary alluvia of the Vistula River are represented by medium sands with a small admixture of gravel in this reach. These deposits are characterised by a low density index, classifying them as loose - moderately dense.

\subsubsection{Gotąb region}

Between km 382 and km 387 (Figure 5) the sub-alluvial bedrock in the Vistula channel is composed of Paleocene gaizes, limestones and marls and their loamy weathering cover, forming an intricate surface [19, 28, 29]. Locally, the sub-alluvial bedrock is represented by sand-gravelly alluvial deposits of a Pleistocene river. The top of both Mesozoic and Pleistocene deposits is covered by a residual lag composed mainly of (Scandinavian) crystalline rocks.

The contemporary channel alluvia are represented by medium and fine sands with rare interbeds of gravels. These deposits are characterised, like those from the Solec nad Wisłą region, by low density index values (loose and slightly denser sediments). The underlying Pleistocene alluvial deposits typically show a much higher density index and can be classified as dense and highly dense. The bedrock of the contemporary alluvial deposits forms an elongated trough in the studied reach with the lowest elevations of its bottom at ca. $100 \mathrm{~m}$ a.s.l. (Figure 3D). To the east of the trough between $\mathrm{km} 383$ and $\mathrm{km} \mathrm{386,} \mathrm{and} \mathrm{to} \mathrm{the}$

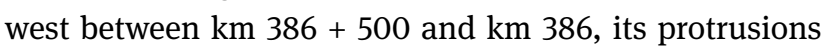
were found with the maximum elevations exceeding 106 $m$ a.s.l.

\subsection{Changes of the thalweg lines arrangement}

\subsubsection{Solec nad Wistą region}

The first bathymetric measurements in the Solec nad Wisła region were performed on July 26, 2004. The echo sounding was carried out in two sections: from $\mathrm{km} 332+500$ to

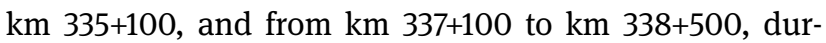
ing low water stages in the channel (Table 1). The main thalweg line in both reaches generally corresponds to the course of the regulatory route (Figure 2A). The elevation of the stream pool bottom (thalweg) attained a value of $120 \mathrm{~m}$ a.s.l., so upstream of the ferry route the top of the sub-alluvial bedrock could be locally exposed. The effect of both the hydro-technical structures and the protrusions of erosion-resistant sub-alluvial bedrock resulted in eversion, forming scarce isolated potholes. Downstream of the 

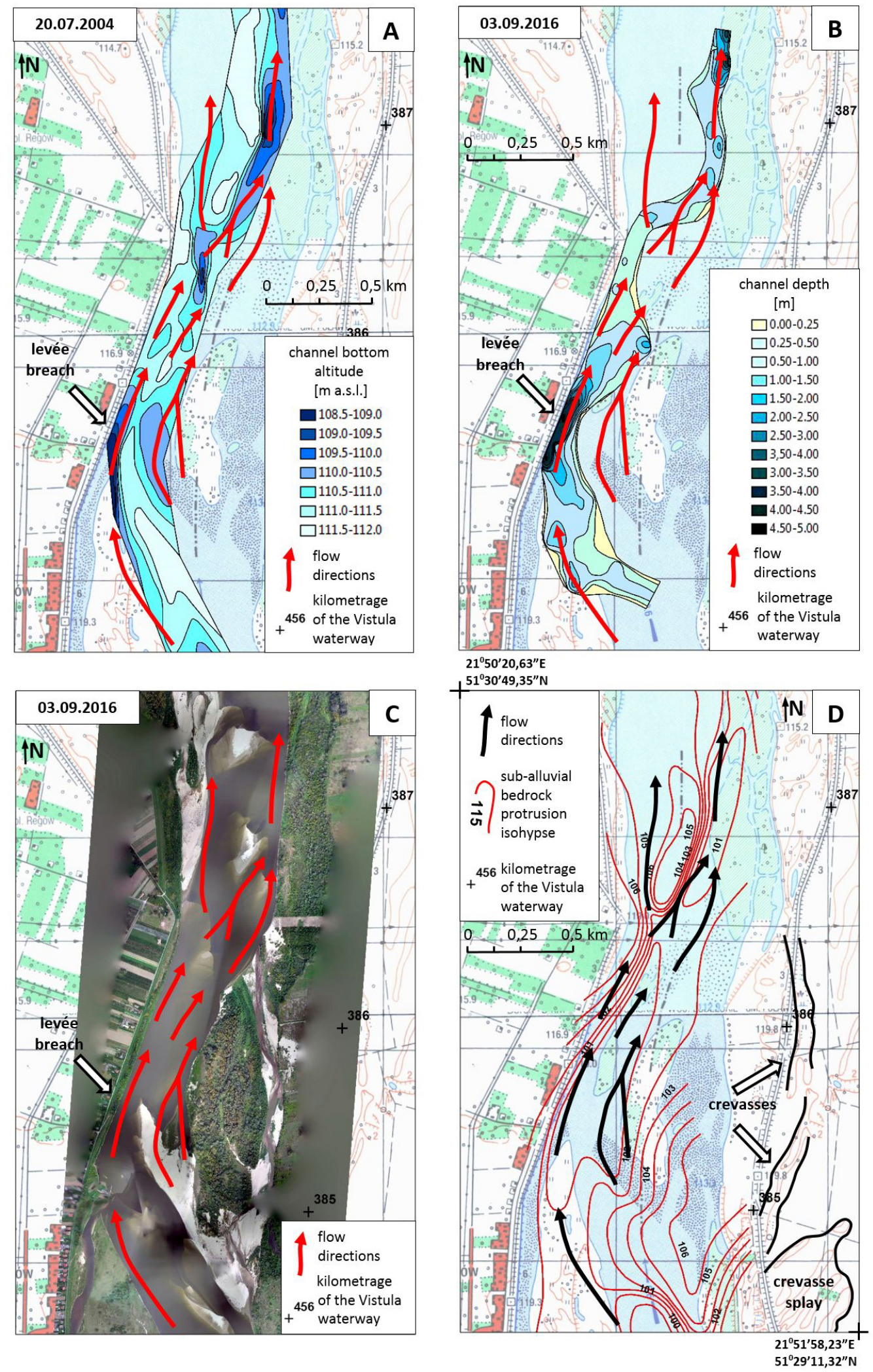

Figure 3: Vistula river thalweg lines arrangement near Gotąb 
2004

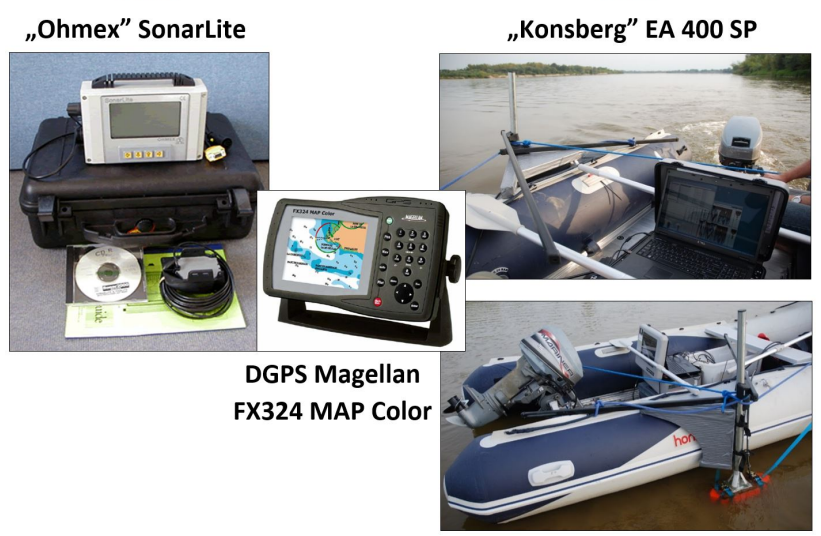

Figure 4: Equipment for bathymetric tests that was used during the investigations

ferry route, near the right bank, there is a branching-off of the main thalweg. This zone is located outside the axis of the regulatory route (!).

Twelve years later (September 05, 2016), an echo sounding was carried out in another river reach from $\mathrm{km}$ 334 to $\mathrm{km} 338+500$, as hydro-technical works were conducted along the ferry crossing zone. The morphology of the part of the channel area where no echo sounding was performed was documented on aerial images. The combined interpretation of the results of bathymetric measurements and the photographic mosaic reveals that the main thalweg path in both reaches examined in 2004 has not changed significantly (Figure 2A, B, C). The maximum depths of the river channel along the main thalweg slightly exceeded $3.5 \mathrm{~m}$. It can therefore be assumed that under these hydrological conditions (low water level in the riverbed) the sub-alluvial bedrock could be exposed only at $\mathrm{km}$ 333. Like in 2004, the aerial images show that the thalweg line occurred near the right bank slightly downstream of the ferry dock (Figure 2C). During the research, a significant deterioration of the condition of the riverengineering structures was found in the channel.

\subsubsection{Gotąb region}

The first bathymetric measurements in this section were carried out on July 20, 2004, during low water level in the channel (Table 1). The results of the measurements show a branching of the main thalweg, which is characteristic of a braided river. Two main thalweg lines can be observed in the entire length of the analysed river reach, which are separated by a string of shallows occupying the axial part of the channel (Figure 3A). The minimum eleva- tions of the channel bottom in this section were $109 \mathrm{~m}$ a.s.l. Such a deep zone occurs, inter alia, near the left bank in the immediate vicinity of the flood embankment $(\mathrm{km} 385$ $385+500$ ). Erosion processes associated with the concentration of the main thalweg in this zone threaten the stability of the flood embankment (Figure 3A). Another zone of minimum elevations was found at $\mathrm{km} 387$. Throughout the entire study section, the top of sub-alluvial bedrock was not exposed on the day of measurements.

Bathymetric measurements conducted 12 years later (September 03, 2016) were also made at low water level in the channel (Table 1). Areas of the greatest depths occurred, as in 2004, near the left bank between km 385

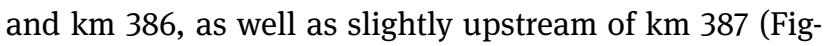
ure $3 \mathrm{~B}, \mathrm{C}$ ). The entire analysed section was dominated by depths not exceeding $0.5 \mathrm{~m}$; therefore, the area covered by the echo sounding research was smaller than in 2004. The thalweg path interpreted based on the obtained bathymetric map and analysis of aerial images is very similar to that found in 2004. As with the case of the Solec region, the condition of the river engineering structures significantly deteriorated over the 12 years.

\section{Discussion}

The basic reason for the variability of the nature of fluvial processes inside the individual sections of river valleys is the geological structure of areas that are crossed by the river [2, 30-32]. The diversity of the susceptibility of rocks that build the valley's substrate manifests itself primarily in the diversification of the valley longitudinal gradients [33] and in distinct changes in the width of valley [34]. Research conducted in many river valleys of the Polish Lowlands has shown a direct relationship between the relief of erosion-resistant sub-alluvial bedrock and the dynamics of flood flows [10,35-37]. This impact is reflected not only in the stability of the thalweg line, but it is also recorded in the geological structure of floodplain as the lithological and geochemical diversity of modern flood deposits $[38,39]$. Beyond the zones of erosion-resistant bedrock protrusions, where there are series of channel alluvia attaining considerable (often more than 19 metres) thicknesses, the channel can be transformed more easily. The thalweg path can change significantly even in stable flow conditions (e.g. during low flows [8]).

The stability of the thalweg path in both analysed reaches of the Vistula River, observed during the research, proves that the geological controls on the course of channel processes can be much more complicated. All hydro- 

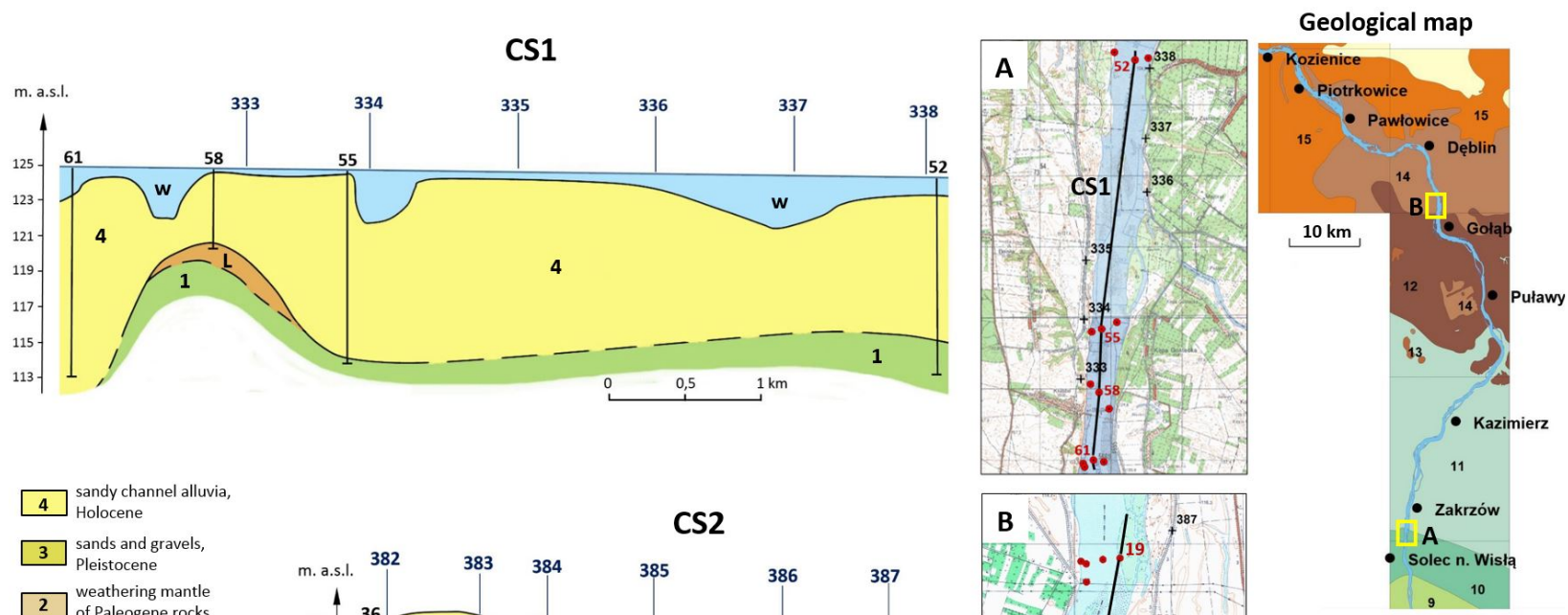
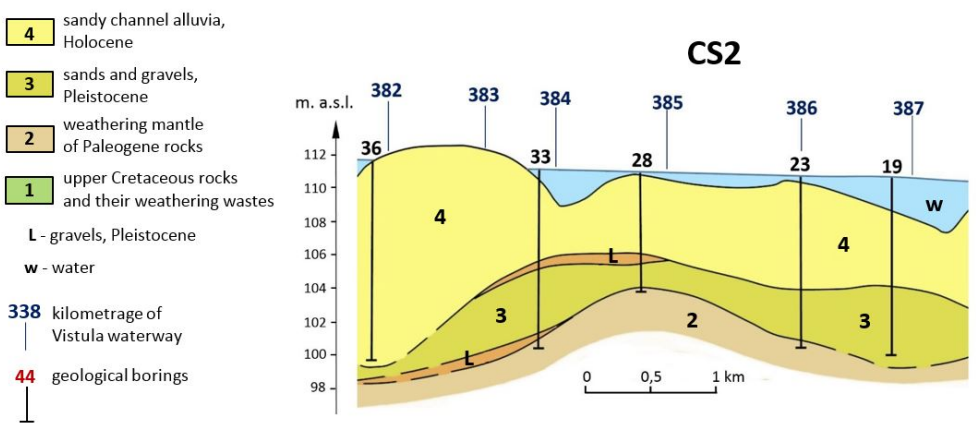

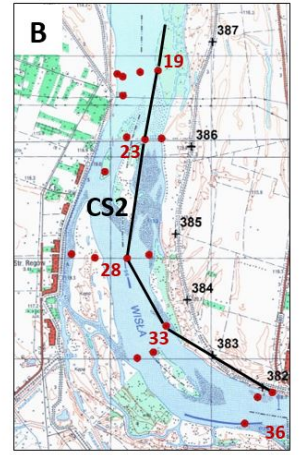

Figure 5: Geological cross-sections of studied channel reaches

graphic measurements, the results of which are presented in this article, were carried out during medium and low water levels in the channel, i.e. when almost the entire bedrock surface was covered with a several-metre layer of contemporary alluvia. The top bedrock surface might have been exposed in the Vistula riverbed in the Solec region only; moreover, only in a very narrow zone. Nevertheless, the main thalweg path in both sections corresponds largely to the relatively complex relief of the top of rocks immediately underlying the contemporary alluvial deposits in the channel (Figures 2, 3).

The sub-alluvial bedrock relief affects directly the water flow pattern in the channel during high water stages, when the bottom surface of the alluvial channel lowers as the water level rises in the channel [20]. The lack of the possibility of channel deepening during flood flows in the zones of protrusions of the erosion-resistant suballuvial bedrock causes the thalweg to be directed into those zones of the channel, where its bottom is being lowered. During the flood fall, these zones of strings of channel bottom depressions are gradually filled with loose material, which is also more easily eroded by the river during medium and low stages. The effect of this phenomenon is the high stability of the thalweg path over time, observed in both sections also under medium and low water stages in the channel (Figures 2, 3). It is worth noting that sev- eral flood events occurred in the analysed sections during the 12-year period between the two series of bathymetric measurements. The most spectacular catastrophic flood of 2010 (Table 1) led not only to large material damage, but also had significant geomorphological effects $[18,40]$. Despite this, the channel zone layout in both sections has not changed significantly, which is another indication of the significance of the geological structure of the channel zone as a factor stabilising its morphology.

Blocking of flood flows by the bedrock culmination also causes the cyclic water penetration to the floodplain surface always in the same places [10, 36, 37, 41, 42]. In the Gołąb region, the traces of such phenomena include a large crevasse splay and flood crevasses located to the right of the channel between $\mathrm{km} 384$ and km 386 (Figure 3D). They formed as a result of flood flows that bypassed an erosion-resistant bedrock culmination with a maximum elevation exceeding $106 \mathrm{~m}$ a.s.l., located on the right bank of the channel at km 385 (Figure 3D).

The highest-elevated parts of the culmination are exposed from under the alluvial layer most often and for the longest time. This causes gradual aggradation of the coarsest material upon their surface. Such material was found on the bedrock surface in both sections under study. Shallows and even islands that formed in this way are characterised by high stability because they are bypassed by 

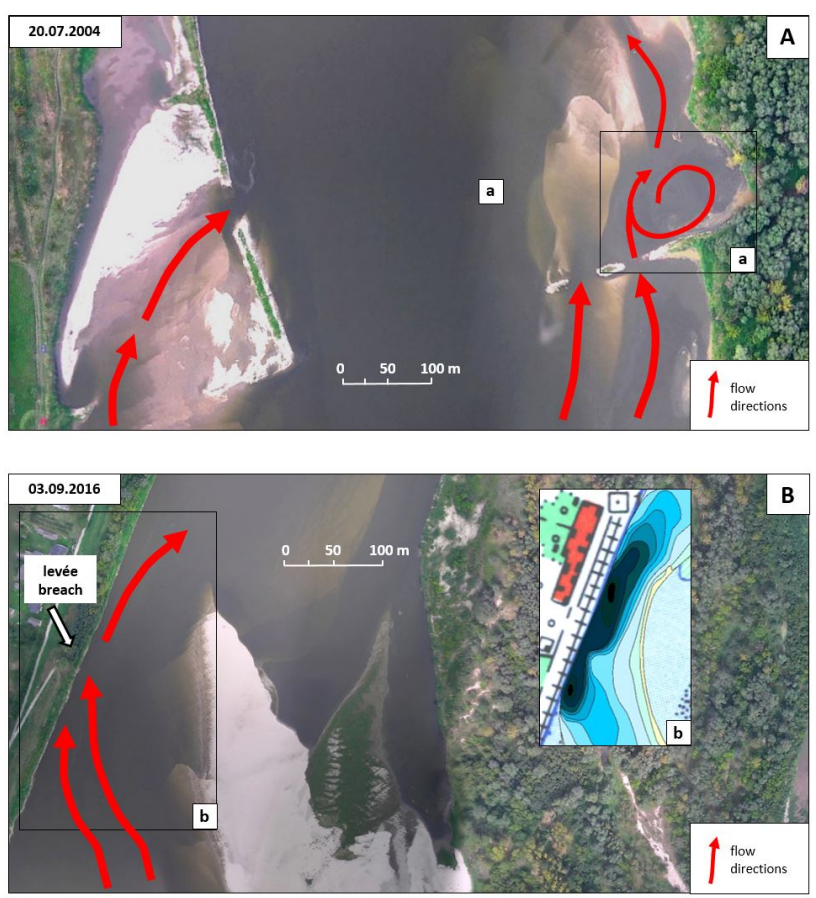

Figure 6: Examples of threat to hydrotechnical constructions related to tendency to specific river thalweg lines arrangement; A: the Solec reach $334 \mathrm{~km}$ of Vistula waterway, B: the Gotąb reach, $385+500 \mathrm{~km}$ of Vistula waterway

the thalweg regardless of the prevailing hydrological conditions (water stages and flow rates in the channel). An example of such a form may be an island existing in the Vistula River channel between $\mathrm{km} 384+900$ and $\mathrm{km} 386+$ 200 , as well as a series of shallows visible in topographic maps and in the photographic mosaic at $\mathrm{km} 387$ of the river course (Figure 3). In the case of the aforementioned island, we can notice that, during about 50 years (the period from updating the content of the topographic map to taking the aerial images), this form has almost doubled in its length and width and has been largely stabilised with woody vegetation.

Of somewhat different origin is the stable thalweg path observed in the Solec region at the right bank dock of the ferry route. Downstream of this area there is a deep zone being a trace of thalweg line shaped under conditions of flood flows. It relates to the relief of the top sub-alluvial bedrock surface (Figure 2A, C, D). This zone was isolated during the construction of an access driveway to the ferry and is currently an area of water stagnation at a time of medium and low flows. During flood flows, however, this depression is sometimes deepened [19].

A thorough analysis of aerial images taken in 2016 made it possible to conclude that a trend towards a specific thalweg path is so strong that it causes damaging of many river engineering structures in the channel (Figure 6). The complex and stable thalweg path within the engineered reach can therefore be another evidence of geological controls on the channel processes. This is confirmed by the repeated destruction of hydro-technical facilities in the channel observed in the same places by the authors during the research conducted on the engineered reaches of the Middle Vistula River. Therefore, by taking into account the geological controls on the channel morphodynamics in river engineering projects we should increase the efficiency and longevity of such investments.

\section{Conclusions}

1. The research was conducted in two different (in terms of morphology and geological structure) sections of the middle Vistula valley: in the gorge zone and beyond it. The main thalweg pattern has not significantly changed in both river channel reaches over a period of 12 years, despite the deterioration of the condition of river engineering structures and the 2010 flood disaster.

2. Stability of the thalweg lines is a combined effect of geological controls (effect of the geological structure) and hydro-technical facilities in the channel. The crucial factor seems to be the relief of the top of erosion-resistant sub-alluvial bedrock.

3. The shape of the top of sub-alluvial bedrock affects the channel zone relief (main thalweg line pattern) not only during flood flows, but also under conditions of medium and low water stages in the channel.

4. The shape of the top sub-alluvial bedrock surface is subjected to modification, mainly as a result of aggradation by coarse residual material. This often causes the formation of stable shallows and islands.

5. The trends of the main thalweg to follow the relief of the surface of erosion-resistant sub-alluvial bedrock should be taken into account in river channel management projects.

\section{References}

[1] Davis W.M., The geographical cycle. Geogr. J., 1899, 14, 481-504

[2] Fryis K., Brierley G., Antecedent controls on river character and behavior in partly confined valley settings: Upper Hunter catchment, NSW, Australia. Geomorphology, 2010, 117, 106-120, doi: 10.1016/j.geomorph.2009.11.015 
[3] Heitmuller F.T., Hudson P.F. and Asquith W.H., Lithologic and hydrologic controls of mixed alluvial-bedrock channels in floodprone fluvial systems: Bankfull and macrochannels in the Llano River watershed, central Texas, USA. Geomorphology, 2015, 232, 1-19, doi: 10.1016/j.geomorph.2014.12.033

[4] Toone J., Rice S.P., Piègay H., Spatial discontinuity and temporal evolution of channel morphology along a mixed bedrockalluvial river, upper Drôme River, southeast France: Contingent responses to external and internal controls. Geomorphology, 2014, 205, 5-16, doi: 10.1016/j.geomorph.2012.05.033

[5] Spotila J.A., Moskey K.A., Prince P.S., Geologic controls on bedrock channel width in large, slowly eroding catchments: Case study of the New River in eastern North America. Geomorphology, 2015, 230, 51-63, doi: 10.1016/j.geomorph.2014.11.004

[6] Falkowski E., Variability of channel processes of lowland rivers in Poland and changes of the valley floors during the Holocene. Biuletyn Geologiczny, 1975, 19, 45-78

[7] Thayer J., B., Ashmore P., Floodplain morphology, sedimentology, and development processes of a partially alluvial channel. Geomorphology, 2016, 269, 160-174. doi: 10.1016/j.geomorph.2016.06.040

[8] Falkowski T., Ostrowski P., Siwicki P., Brach M., Channel morphology changes and their relationship to valley bottom geology and human interventions; a case study from the Vistula Valley in Warsaw, Poland. Geomorphology, 2017, 297, 100-111, doi: 10.1016/j.geomorph.2012.06.020

[9] Parker C., Simon A. and Thorne C. R., The effect of variability in bank material properties on riverbank stability: Goodwin Creek, Mississippi. Geomorphology, 2008, 101, 533-543. doi: 10.1016/j.geomorph.2008.02.007

[10] Falkowski T., Geomorphological analysis of a The Vistula River valley in evaluating the safety of regulation structures. Acta Geol. Pol., 2007, 57, 3, 377-390

[11] Falkowski E., Evolution of the Holocene Vistula from Zawichost to Solec with an engineering-geological prediction of further development. Biuletyn Instytutu Geologicznego, 1967, 198, Tom IV, 57-148, [in Polish]

[12] Burge L.M., Lapointe M.F., Understanding the temporal dynamics of the wandering Renous River, New Brunswick, Canada. Earth Surf. Process. Landf., 2005, 30, 1227-1250, doi: 10.1002/esp.1196

[13] Takagi T., Oguchi T., Matsumoto J., Grossman M.J., Sarker M.H., Matin M.A., Channel braiding and stability of the Brahmaputra River, Bangladesh, since 1967: GIS and remote sensing analyses. Geomorphology, 2007, 85, 294-305, doi: 10.1016/j.geomorph.2006.03.028

[14] Schumm S.A., Geomorphic thresholds: the concept and its applications. Trans. Inst. Br. Geogr., 1979, 4 (4), 485-515

[15] Nanson G.C., Anabranching and anastomosing rivers. In: Shroder, J. (Editor in Chief), Wohl, E. (Ed.), Treatise on Geomorphology. Academic Press, San Diego, CA, vol. 9, Fluvial Geomorphology, 2013, 330-345

[16] Gurnell, A., State of science plants as river engineers. Earth Surf. Process. Landf., 2014, 39, 4-25, doi: 10.1002/esp.3397

[17] Ondruch J., Màčka Z., Response of lateral channel dynamics of lowland meandering river to engineering-derivet adjustments an example of the Morava River (Czech Republic). Open Geosci., 2015, 7, 588-605, doi: 10.1515/geo-215-0047
[18] Wierzbicki G., Ostrowski P., Mazgajski M. Bujakowski F., Using VHR multispectral remote sensing and LIDAR data to determine the geomorphological effects of overbank flow on a floodplain (the Vistula River, Poland). Geomorphology, 2013, 183, 73-81, doi: 10.1016/j.geomorph.2012.06.020

[19] Falkowski T., Factors of natural stability of the Middle Vistula River channel zones. Wydawnictwo SGGW, Warszawa, 2006, [in Polish]

[20] Leopold L.,B., Wolman M.G., Miller J.P., Fluvial processes in geomorphology. W.H. Freeman \& Co, San Francisco, 1964

[21] Pożaryski W., Maruszczak H. Lindner L., Chronostratigraphy of the Pleistocene sediments and development of the Middle Vistula valley, with particular emphasis on the gorge zone through the South-Polish highlands. Prace Państwowego Instytutu Geologicznego, 1994, CXLVII, 57 [in Polish]

[22] Żarski M., Explanations for the Detailed Geological Map of Poland in 1: 50,000 scale, Dęblin sheet. Państwowy Instytut Geologiczny, Warszawa, 1993 [in Polish]

[23] Starkel L., Evolution of the Vistula River valley since the last glaciation till present. Series: Monographs - Polska Akademia Nauk. Instytut Geografii i Przestrzennego Zagospodarowania im. Stanisława Leszczyckiego, Warszawa, 2001, [in Polish]

[24] RZGW Warszawa, Characteristics of rivers and assessment of their needs, 2017 https://warszawa.rzgw.gov.pl/_data/ assets/pdf_file/0017/6290/Charakterystyka-rzek-orazocena-ich-potrzeb.pdf, date: 20.04.2017 [in Polish]

[25] Jokiel P., Marszelewski W., Pociask-Karteczka J., Hydrologia Polski, PWN, Warszawa, 2017

[26] Ostrowski P., Falkowski T., Karczmarz D., Mądrzycki P., Szkudlarz H., The usefulness of low-altitude aerial photography for the assessment of channel morphodynamics of a lowland river. Ann. Warsaw Univ. of Life Sci. - SGGW, Land Reclam., 2017, 49, 2, 95-106

[27] Maruszczak H., Vistula in Lublin region. In: Piskozub A. (Ed.), Vistula; river monograph; Wydawnictwo Komunikacji i Łączności, Warszawa, 1982, [in Polish]

[28] Żarski M., Detailed Geological Map of Poland (1:50 000), Puławy sheet. Państwowy Instytut Geologiczny, Warszawa, 1998, [in Polish]

[29] Żarski M., Explanations for the Detailed Geological Map of Poland in 1: 50,000 scale, Puławy sheet. Państwowy Instytut Geologiczny, Warszawa, 1998, [in Polish]

[30] Migiros G., Bathrellos G.D., Skilodimou H.D., Karamousalis T., Pinios (Pineus) River (Central Greece): Hydrological - geomorphological elements and changes during the Quaternary. Cent. J. Geosci., 2011, 3(2), 215-228, doi: 10.2478/s13533-011-0019-1

[31] Kamberis E., Bathrellos G.D., Kokinou E., Skilodimou H.D., Correlation between the structural pattern and the development of the hydrographic network in a portion of the Western Thessaly Basin (Greece). Cent. Eur. J. Geosci. 2012, 4(3), 416-424, doi: 10.2478/s13533-011-0074-7

[32] Schanz S.A. and Montgomery D.R., Lithologic controls on valley width and strath terrace formation. Geomorphology, 2016, 258, 58-68, doi: 10.1016/j.geomorph.2016.01.015

[33] Zahra T., Paudel U., Hayakawa Y.S., Oguhi T., Knickzone Extraction Tool (KET) - A new ArcGIS toolset for automatic extraction of knickzones from a DEM based on multi-scale stream gradients. Open Geosci., 2017, 9, 73-88, doi: 10.1515/geo-2017-0006

[34] Falkowski T., The importance of recognition of polygeny for the rational utilisation of river valleys in Polish Lowland. in: Mari- 
nos P.G, Koukis G.C., Tsiambaos G.C., Stournaras G.C. (eds) Proceedings International Symposium "Engineering Geology and the Environment”, Athens, Greece, A.A.BALKEMA, 1997, 107-111

[35] Falkowski T., Basement of the alluvia influence on the channel pattern in example of selected reach of the Pilica River. Ann. Warsaw Univ. of Life Sci. - SGGW, Land Reclam., 2010, 42 (1), 93-104

[36] Ostrowski P., The diversity of erosional landforms in the Bug river valley in the Podlasie Region (NE Poland). Przegląd Naukowy - Inżynieria i Kształtowanie Środowiska, 2015, 70, 350-360, [in Polish]

[37] Wierzbicki G., Ostrowski P., Falkowski T., Mazgajski M., Geological setting control of flood dynamics in lowland rivers (Poland). Sci. Total Environ. 2018, 636, 367-382, doi: 10.1016/j.scitotenv.2018.04.250

[38] Falkowska E., Falkowski T., Trace metals distribution pattern in floodplain sediments of a lowland river in relation to contemporary valley bottom morphodynamics. Earth Surf. Process. Landf. 2015, 40 (7), 876-887, doi: 10.1002/esp.3680
[39] Falkowska E., Falkowski T., Tatur A., Kałmykow-Piwińska A., Floodplain morphodynamics and distribution of trace elements in overbank deposits, Vistula River Valley Gorge near Solec nad Wistą, Poland. Acta Geol. Pol., 2016, 3, 541-559, doi: 10.1515/agp-2016-0025

[40] Wierzbicki G., Ostrowski P., Samulski M., Bujakowski F., The impact of geological setting into a dynamics of extreme floods - a case study of the 2010 flood event in the Vistula valley. Infrastruktura i Ekologia Terenów Wiejskich, Polska Akademia Nauk, Oddziat w Krakowie, 2012, 3/III/2012, 27-41, [in Polish]

[41] Bujakowski F., Falkowski T., The use of airborne laser scanning in the assessment of groundwater flow conditions in floodplain deposits. Przegląd Geologiczny, 2017, 65, 7, $443-449$ [in Polish]

[42] Falkowska E., The significance of morphogenetic analysis in the assessment of soil-water conditions in Quaternary sediments. Geomorphology, 2015, 246, 420-432, doi: 10.1016/j.geomorph.2015.06.039 